\title{
CONCENTRATIONS OF NUCLEIC ACIDS AND PROTEIN IN THE MOUSE OVIDUCT DURING THE OESTROUS CYCLE AND AFTER STEROID REPLACEMENT
}

\author{
F. H. BRONSON AND T. H. HAMILTON \\ Department of Zoology, The University of Texas, \\ Austin, Texas 78712, U.S.A.
}

(Received 3rd November 1970)

Comparatively little is known about cyclic activity in the oviducts of mammals having relatively short oestrous cycles. For example, the literature is even in conflict on the basic question of what histological changes in the oviducal epithelium can be correlated with various stages of the oestrous cycle (see Brenner, 1969). As far as we know, neither the rat nor the mouse oviduct has been the subject of any detailed investigations using the traditional techniques of ovariectomy and steroid replacement. Furthermore, oviducal nucleic acids have not been extensively examined in any mammalian species. The results now reported document alterations in the concentrations of RNA and protein in the mouse oviduct during the oestrous cycle and, in addition, show the partial dependence of oviducal RNA metabolism on the circulating levels of ovarian hormones, particularly oestrogen. The concentration of oviducal DNA was unaltered during the cycle, but our data point to a small decrease in DNA in the oviducts of chronically ovariectomized females as well as a compensatory increase following oestrogen replacement.

The Yale Swiss albino females used in the study of the oestrous cycle were housed in groups of ten and were kept adjacent to mature males to promote rapid cycling (see Bronson, 1968). Oestrous cycles were monitored by vaginal smears taken daily for 2 weeks before killing at each of the four stages of the cycle. Pro-oestrus was defined as the time of appearance of a vaginal smear consisting primarily of nucleated epithelial cells with possibly a few leucocytes and cornified cells, oestrus as the first smear containing primarily cornified cells, metoestrus as the initial reappearance of leucocytes, and dioestrus as the 2nd day of a typically leucocytic type of vaginal smear. Vaginal smears were taken from all females between 09.00 and 10.00 hours and the females were subsequently killed between 12.00 and 14.00 hours. Only animals possessing characteristically short cycles were used. A second group of adult females were ovariectomized and, after a further 40 days, were injected daily either for 1 or 4 days with $1 \mu \mathrm{g}$ of oestradiol benzoate, $200 \mu \mathrm{g}$ of progesterone or the solvent alone $(0 \cdot 1 \mathrm{ml}$ of corn oil, subcutaneously). The animals were killed $24 \mathrm{hr}$ after their last injection. The killing time (13.00 hours) and the age ( 80 to 90 days) 
of the animals used in the second investigation were the same as in the investigation of the oestrous cycle. In all experiments, each pair of oviducts was homogenized and the DNA, RNA and protein were determined by the methods of Burton (1956), Ceriotti (1955) and Lowry, Rosebrough, Farr \& Randall (1951), respectively. Each mean value reported is based on ten to thirteen separate determinations, i.e. the paired oviducts of ten to thirteen females.

The wet weight of the oviduct as well as its concentration of RNA and protein varied significantly during the oestrous cycle, but no variation was observed in the concentration of DNA (Table 1). The percentage increase between dioestrus and pro-oestrus was $16 \%$ for wet weight, $18 \%$ for RNA, and $26 \%$ for total protein $(P<0.02$ in each case). The wet weight of the organ and its concentration of RNA and protein decreased $31 \%, 49 \%$ and $45 \%$, respectively, as a consequence of ovariectomy (compared to dioestrous values;

TABLE 1

OVIDUCAL WEIGHT AND CONTENT OF DNA, RNA AND PROTEIN IN THE MOUSE AS A FUNCTION OF THE STAGE OF OESTROUS CYCLE OR OF STEROID REPLACEMENT (MEAN士S.E.)

\begin{tabular}{l|cccc|c}
\hline \multirow{2}{*}{ Group } & \multicolumn{4}{|c|}{ Paired oviducts } & $\begin{array}{c}\text { Uterine } \\
\text { weight } \\
(m g)\end{array}$ \\
\cline { 2 - 6 } & $\begin{array}{c}\text { Weight } \\
(\mathrm{mg})\end{array}$ & $\begin{array}{c}\text { DNA } \\
(\mu \mathrm{g})\end{array}$ & $\begin{array}{c}R \mathcal{N N A} \\
(\mu \mathrm{g})\end{array}$ & $\begin{array}{c}\text { Protein } \\
(\mu g)\end{array}$ & \\
\hline Intact animals & & & & & \\
$\quad$ Dioestrus & $3 \cdot 2 \pm 0 \cdot 2$ & $39 \pm 2$ & $45 \pm 2$ & $314 \pm 19$ & $70 \cdot 3 \pm 7 \cdot 2$ \\
Pro-oestrus & $3 \cdot 7 \pm 0 \cdot 1$ & $38 \pm 2$ & $53 \pm 2$ & $392 \pm 14$ & $122 \cdot 6 \pm 5 \cdot 9$ \\
Oestrus & $3 \cdot 6 \pm 0 \cdot 1$ & $36 \pm 1$ & $46 \pm 1$ & $345 \pm 15$ & $88 \cdot 1 \pm 5 \cdot 7$ \\
Metoestrus & $3 \cdot 4 \pm 0 \cdot 1$ & $36 \pm 1$ & $45 \pm 2$ & $335 \pm 18$ & $60 \cdot 0 \pm 5 \cdot 2$ \\
\hline Ovariectomized animals & & & & & \\
Oil, 1 and 4 days* & $2 \cdot 2 \pm 0 \cdot 1$ & $32 \pm 1$ & $23 \pm 1$ & $171 \pm 10$ & $14 \cdot 5 \pm 1 \cdot 2$ \\
Oestradiol, 1 day & $2 \cdot 6 \pm 0 \cdot 2$ & $32 \pm 2$ & $31 \pm 2$ & $217 \pm 14$ & $30 \cdot 1 \pm 2 \cdot 1$ \\
Oestradiol, 4 days & $4 \cdot 1 \pm 0 \cdot 3$ & $38 \pm 3$ & $48 \pm 2$ & $363 \pm 23$ & $80 \cdot 2 \pm 3 \cdot 7$ \\
Progesterone, 1 day & $2 \cdot 5 \pm 0 \cdot 2$ & $31 \pm 2$ & $26 \pm 3$ & $185 \pm 18$ & $15 \cdot 8 \pm 1 \cdot 0$ \\
Progesterone, 4 days & $1 \cdot 8 \pm 0 \cdot 1$ & $28 \pm 1$ & $18 \pm 1$ & $128 \pm 5$ & $17 \cdot 7 \pm 1 \cdot 2$ \\
\hline
\end{tabular}
days.

* Pooled data for animals given oil for 1 day and those given oil daily for 4

$P<0.001$ in each case). A single injection of $1 \mu \mathrm{g}$ of oestradiol resulted in a significant increase in the concentration of oviducal RNA in the ovariectomized animals $(P<0 \cdot 01)$, whereas the wet weight and the RNA and protein concentrations of the organ were all restored to their normal values after four daily injections of oestradiol (Table 1). Four daily injections of progesterone significantly depressed the concentration of RNA and protein in the oviduct of the ovariectomized animal $(P<0.05)$. The concentration of DNA was not significantly decreased by ovariectomy, if compared to the levels observed during metoestrus and oestrus. Compared to the level at dioestrus, however, the DNA of the oviduct was significantly decreased by ovariectomy $(P<0 \cdot 05)$. Four daily injections of oestradiol returned the concentration of DNA to the normal level.

Our experiments indicate that synthesis of RNA and protein in the mouse 
oviduct is regulated by oestrogen during the oestrous cycle as well as after ovariectomy. The level of DNA is apparently unaltered during the cycle but in our experiments, the DNA showed a small decrease at 40 days after ovariectomy and an increase of the same magnitude after oestradiol replacement (Table 1). Our data further suggest a small decrease in the oviducal levels of RNA and protein in the ovariectomized animal treated with progesterone. Nevertheless, an analysis of the whole-organ ratios of RNA to DNA failed to confirm the latter observation (Text-fig. 1).

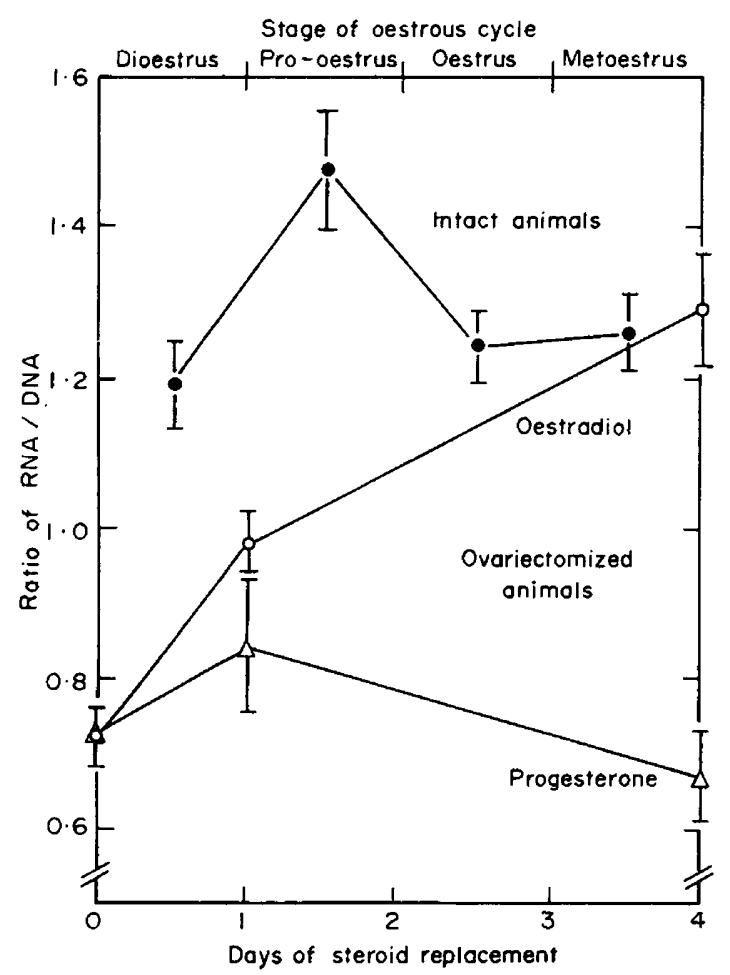

TEXT-FIG. 1. Ratio of RNA to DNA in the oviduct of the mouse, as a function of stage of oestrous cycle $(\bullet)$, or of oestradiol $(O)$ or progesterone $(\Delta)$ replacement (mean \pm S.E.).

Two additional points are noteworthy. First, within the framework of the schedule of smearing and killing employed, the peak activity in both the oviduct and the uterus of the mouse occurred at the stage defined by vaginal smears as pro-oestrus (Table 1). A previous investigation of the nucleic acids of the mouse uterus, performed with the same schedule of smearing and killing, resulted in the same conclusion (Desjardins, Chapman \& Bronson, 1970). The latter investigation showed that the concentration of RNA in the uterus had dropped sharply by early afternoon on the day after pro-oestrus, i.e. the day indicated by a typical oestrous smear. Second, the oviduct may change more markedly between pro-oestrus and oestrus than does the uterus. The amount of RNA in the oviduct apparently returned to dioestrous level by mid-day on the day after pro-oestrus (Table 1). Ovarian secretion of oestrogen is known to 
begin its decline during the evening of pro-oestrus in the rat (Hori, Ide \& Miyaki, 1968). If essentially the same temporal pattern of oestrogen secretion occurs in the mouse, then we can assume that almost all of the oestrogeninduced RNA in the oviduct turns over in less than $16 \mathrm{hr}$. This turnover would be even more rapid if the peak level in circulating oestrogen occurred later in the evening in the mouse. Rapid turnover of RNA synthesized in response to endogenous ovarian hormones or to oestrogen replacement has already been documented in the rat uterus (Hamilton, Widnell \& Tata, $1967 \mathrm{a}, \mathrm{b})$.

In conclusion, it can be stated that the metabolism of RNA and protein in the oviduct, at least as measured by variations in the whole-organ concentrations, changes rapidly after ovulation and experimental manipulation of endogenous levels of oestrogen. Whether the oviducal nucleic acids and proteins thus induced are important factors in fertilization and early development remains to be determined.

This work was supported by U.S. Public Health Service Contract Grant 70-2159 given by the Center for Population Research, The National Institute for Child Health and Human Development.

\section{REFERENCES}

BRENNER, R. M. (1969) The biology of oviductal cilia. In: The Mammalian Oviduct, p. 203. Eds. E. S. E. Hafez and R. J. Blandau. The University of Chicago Press.

Bronson, F. H. (1968) Pheromonal influences on mammalian reproduction. In: Perspectives in Reproduction and Sexual Behavior, p. 341. Ed. M. Diamond. The University of Indiana Press, Bloomington.

BuRton, K. (1956) A study of the conditions and mechanisms of the diphenylamine reaction for the colorimetric estimation of deoxyribonucleic acid. Biochem. F. 62, 315 .

Cerrottr, G. (1955) Determination of nucleic acids in animal tissues. F. biol. Chem. 214, 59.

Desjardins, C., Chapman, V. M. \& Bronson, F. H. (1970) Hypophyseal lH and Fsh release and uterine nucleic acid changes during the mouse estrous cycle. Anat. Rec. 167, 465.

Hamilton, T. H., Widnell, C. G. \& TATA, J. R. (1967a) Metabolism of ribonucleic acid during the oestrous cycle. Nature, Lond. 213, 922.

Hamilton, T. H., Widneli, C. C. \& Tata, J. R. (1967b) Synthesis of ribonucleic acid during early estrogen action. F. biol. Chem. 243, 408.

HoRI, T., IDE, M. \& MrYAKI, T. (1968) Ovarian estrogen secretion during estrous cycle and under influence of exogenous gonadotropins in rats. Endocr. jap. 15, 215.

Lowry, O. H., Rosebrough, N. J., FARR, A. L. \& Randall, P. J. (1951) Protein measurement with the folin phenol reagent. F. biol. Chem. 193, 265. 